\title{
A QUARTER-CENTURY OF RUSSIAN ACADEMY OF NATURAL SCIENCES (five steps up)
}

(report on the anniversary of the Academy of General Meeting

Moscow, Cathedral of Christ the Savior, 24.11.2015)

\section{Oleg L. Kuznetsov}

Russian Academy of Natural Sciences, http://www.raen.info

119002 Moscow, Russian Federation

info@raen.ru

Abstract. Summarized the history and formation of the largest Russian public expert organization - the Russian Academy of Natural Sciences, established a turning point for the country's 90 years of the 20 th century. Marked and commented on the five stages of the development of the academy: the classic organization of sections, sections of gosprioritetam, thematic sections, regional sections and innovative sections. The motto of the Academy of Natural Sciences - interdisciplinarity and integration of diverse knowledge. The symbol of the Academy is the VI Vernadsky, the Academy is actively promoting Russian cosmism school. RANS initiate registration of scientific discoveries, is widely involved in the educational sector of the country, is the founder in 1994 of the University "Dubna", one of the best universities in the country for the recognition of experts. Publishing RANS - thousands of titles, the Bulletin of Natural Sciences, many sections and departments have their own magazines, including RENSIT. The Academy is widely recruited to participate in international forums (Summits), committees and festivals. As an all-Russian scientific organization, RANS plays an important role one of the cells of civil society, which is consolidating around a large domestic intellectual potential of performing a stabilizing role in the country.

Keywords: expertise, nongovernmental Academy of Sciences, sections and branches of Academy, interdisciplinary, Russian cosmism, educational sphere, publishing, international forums

PACS: 01.10.Fv

Received 27.11.2015

RENSIT, 2015, 7(2):212-216

DOI: $10.17725 /$ rensit.2015.07.212

\section{Contents}

1. INTRODUCTION (212)

2. ORIGINS, MOTIVATIONS AND THE FIRST PARTICIPANTS OF THE EVENT (213)

3. Formation STAGES OF ACADEMY (214)

4. BASIC PRINCIPLES (214)

5. МоTto RANS - INTERDISCIPLINARITY AND INTEGRATION OF HETEROGENEOUS KNOWLEDGE (214)

6. FORUMS AND EVENTS (214)

7. RANS AND SCIENTIFIC DISCOVERIES (215)

8. RANS AND EDUCATIONAL SPHERE (215)

9. Publishing activities RANS (216)

10. Russian COSMists. VERnADSKY - A SYMbOL OF THE ACADEmy (216)

11. Conclusion (216)

\section{INTRODUCTION}

Dear colleagues, comrades!

High academic community!

Passed 25 years since the birth of intention on the creation in the USSR (Russia) the new alternative Academy of Sciences, based on the role of civil society institutions in the development of the scientific sphere of the country.

Congratulations to all the members of the Academy to the fact that this long and difficult path our Academy passed, at highly worthily ministration Russian, science, education and upbringing of the younger generation.
Founders of Academy came from the fact that science - this is an open system, immersed in society and associated with it numerous feedbacks.

International experience has shown that the scientific structures, organized and operating beyond principles of civil society, are prone to degradation.

Our solemn assembly held in the special period of life of the country and in the special, holy place of the capital - in Christ the Savior Cathedral.

I will express a few thoughts about the combination of the time and place of our meeting.

Today the whole world, and Russia in particular, speaking in the language of synergy, are living in "a regime with peaking." Civilization has gone through another bifurcation point, now it is important, on what

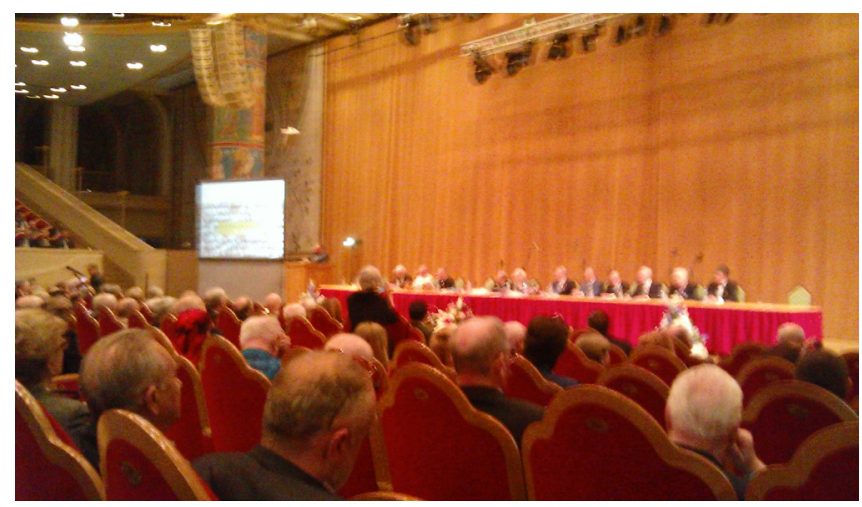


channel will the global development and the development of Russia.

Every day brings us more and more dramatic events. The world is on the "razor's edge" - on the edge of chaos. Our scientific community has an understanding of the causes of this phenomenon. About it scientists RANS wrote not once. World's global crisis was caused, first of all, a huge difference between speculative capital, issued by the Federal Reserve, and the real GDP.

This crisis will not be overcome unless will not happen a change of values among the billions of people and the transition from a consumer society to a society of creation. It is necessary the so called noosphere transition - from the clever to the spiritual. And in this regard the fundamental importance has the place where we are now - the Cathedral of Christ the Savior.

Perhaps many people have a question: why scientific meeting going in the temple? The answer is obvious. Russian Academy of Natural Sciences and was established as a scientific organization, in which is realized the synthesis of natural, technological and humanitarian knowledge. But the main thing - we are today witnessing and participants in a new synthesis "scientific knowledge" and "faith." Science and religion - two independent channels, which lead to a more holistic understanding of the world. And here the great role played by public institutions.

On the interval 90 and 00 -ies. in the world of science has undergone tremendous and important for us changes due to penetration into the mass consciousness of the achievements of integrative trends in science, as a dynamics of the open non-linear systems, synergetics the science of self-organizing complex systems of any nature, and the nonequilibrium thermodynamics, which lead to the understanding of the interaction of "order" and "chaos" in the surrounding world.

Naturally, the new understanding of the world directly affected the philosophy and stages of development of our Academy.

In the article "A quarter century of RANS" in the journal "The honor of the Fatherland» (№ 11-12 (109110), 2015) and in the reports submitted by sections and divisions, provides detailed analytical information about the activity of RANS in the intervening period.

Therefore (with considering time-limit), I will outline and comment briefly on the most striking stages and traits of life Academy.

\section{ORIGINS, MOTIVATIONS AND THE FIRST PARTICIPANTS EVENTS}

The fact is that a significant part of the expert community in Russia already in the late 80s had an absolutely clear picture of the transition from a planned to a market economy. Representatives of industry and university science understanded how easy it can be dissolved in a reformist chaos the extremely important and relatively thin layer of professionals, and foresaw the danger of the loss of leadership of Russian in scientific and technological development. And at this period when the science in the country was left to fend for themselves, Russian scientists have realized the need for new, more viable forms of scientific associations.

At that time still operated USSR Academy of Sciences, which is known worldwide for his outstanding work in the field of mathematics, physics, chemistry, earth sciences, biology and others. Yet worked large industrial research institutes and university laboratories in a wide range of areas. Even the word "scientist", "Professor" in the public and state consciousness sounded weighty.

But just then the Supreme Council of the Russian Federation addressed to the scientific community of Russia with a request to give their suggestions on the principles of the creation and organization of the Russian Academy of Sciences.

The initiative group of professors of Moscow and Leningrad (Mineev, Kapitsa, Sorokhtin, fursey, Vorontsov Tyminsky and others) has put forward the idea of creation of the Russian Academy of Natural Sciences as an alternate scientific organization. Its base should become the authors of scientific discoveries, published in the Great Soviet Encyclopedia (volum "Scientific discoveries in the USSR in thirty years").

Academy was formed as a multidisciplinary scientific organization under the leadership of a talented scientist and geologist Professor Dmitry Andreyevich Mineeva. After his untimely death in 1992 the leadership of Academy has been entrusted to me. An important role in the fate of the Academy played its first Chief Scientific Secretary Professor Vladimir G. Tyminsky. He initiated the establishment of a number of innovative sections and departments.

Among the first members of the Academy - are outstanding scientists and organizers of science as Averincev, Ahrens, Basniev, Belyakov, Bestuzhev-Lada, Vorontsov, Zeldovich, Kapitsa, Kozlovsky, Lapin, Makogon, Monin, Nikolsky, Petrov, Petrovsky, Pirumov, Radkevich, Rachmanin, Severin, Senchagov, Sorokhtin, Fedorov, Hain, Chelyshev, Chereshkin, Shafranovsky, Shevchenko and many others. Their intellectual potential allowed for a short time to deploy a multi-faceted activity on to revive domestic science.

Idea of creation of RANS in the 90 s found widespread and active support of the scientific community and the leadership of the country's leading universities: Lomonosov MSU, Bauman Moscow State Technical University, Russian State Geological Prospecting University n. a. Sergo Ordzhonikidze (MGRI-RSGPU), Gubkin Russian State University of Oil and Gas, Moscow Mining and the Leningrad Mining Institute, the University of Leningrad, as well as the largest universities in Saratov, Kazan, Novosibirsk, Tomsk, Tyumen, Kemerovo, and others.

RANS with first her steps supported the leading representatives of the Academy of Sciences of the USSR, among them - RAS academicians Likhachev, Sadovnichy, Flerov, Kadyshevskii, Sisakyan, Yanshin, Prokhorov, Grigoryan Laverov, Dmitriev, Chariton, Trofimuk, Shiloh, Fedorov, and others.

The same position occupied by scientists from dozens of leading industry research institutes, design bureau, large industrial associations in Moscow and St. Petersburg (SSC Geosystems Research Institute, AllRussian Research Institute of Mineral Resources, AllRussian Research Institute of oil, Schmidt Institute of Physics of the Earth of the USSR Academy of Sciences, the Institute of Oceanology of the USSR Academy of Sciences and many others). 
This support allowed to form a staff of RANS from the first-class scientists, specialists and experts. In many areas of science and practice they were the key persons.

To successful development of RANS contributed a huge work of the St. Petersburg branch and its units (vice-presidents Fursey, Denisov and Novikov).

\section{FORMATION STAGES OF ACADEMY}

In the development of the Academy can distinguish five steps (steps up):

- in the first phase (1991-1992) arised sections that repeated the classic structure of natural sciences, "Physics", "Chemistry", "Mathematics", "Earth Science", "Biomedicine", "Biology and Ecology";

- in the second phase (1992-1993) in connection with the emergence of new research priorities (socially important for updating and self-determining Russian society) appeared sections "Geopolitics and Security", "Mining and Metallurgy", "Russian encyclopedia", "Problems of macroeconomic and social market economy", "Problems of education and support of young scientists", "Economics and Sociology ";

- in the third phase (1993-1995) were organized the sections "Science of forest", "Noosphere knowledge and technology", thematic divisions "Humanities and creativity", "Multi-sectoral ecological and economic systems studies", "Oil and Gas", "Applied Mathematics", "Science and Theology";

- in the fourth phase (1995-2000) the activity of Academy acquired a nationwide character, in its structure was organized about 100 regional and thematic departments. Originally incorporated as the Academy of Natural Sciences of Russian Federation, in 1996 it received the status of AllRussian public organization called "The Russian Academy of Natural Sciences";

- in the fifth stage (2001 - present) further development received the directions, associated with the solution of new technological and innovation problems, as reflected in the appearance of departments "Scientific basis for regulation of natural monopolies", "Information and communication technologies", "Problems of Communication Economics" and others. In these years were created 10 new regional departments. The Academy has started publishing his journal "Bulletin of RANS".

\section{BASIC PRINCIPLES}

In the early 90-ies were formed scientific ideas about the evolution of social and cultural systems (nature - society - people). It came the realization that they develop as an open, complex, non-linear system by self-organization.

Therefore RANS was built on the understanding and use of the most important principles of synergetics (Haken, Kurdyumov, Malinetskii, Kapitsa, Knyazev):

- the ability of open natural and social systems to self-organization and development on the path of increasing complexity and diversity;

- leading (determining) role in the development of socalled "order parameters"; Among these parameters, we consider the level of creative activity and passionarity of the team members.
It was clear that the development of open nonlinear systems necessarily connected with the emergence of the system of new degrees of freedom that allow the emergence of new elements, responsible for the reaction to the emergence of problems and threats in the world.

The large number of degrees of freedom provides the ability to self-improvement.

\section{MOTTO RANS - INTERDISCIPLINARITY AND INTEGRATION OF HETEROGENEOUS KNOWLEDGE}

Precisely at the Academy was founded strategic and interdisciplinary direction - sustainable development of socio-natural systems. Already in the early stages of formation it was clear the need for the synthesis of natural, human and technological knowledge under the supervision of the general culture of the scientific community.

These ideas have been implemented through the creation and successful development of the sections "Man and Creation" and "Russian encyclopedia."

Precisely interdisciplinarity allowed to realize the strategic projects:

National Security Concept. Leader - Chairman of the section "Geopolitics and Security" Pirumov. This is the first in the history of Russia concept of national security. Many of the provisions of the fundamental scientific work are reflected in the key documents of the Russian Federation Security Council.

The concept of economic security of Russia. Leader Chairman of the section "Problems of macroeconomic and social market economy" Senchagov.

The concept of information security in Russia. Leader Chairman of the section "Informatics and Cybernetics" Chereshkin.

Mineral resources base of Russia. Leader - Chairman of the "Geological Prospecting Department" Kozlovsky.

Drinking water and water resources. Leader - Chairman of the section "Biomedicine" Rachmanin.

Prions and prion diseases of bumans and animals. Leader - Chairman of the Department of the section "Biomedicine" Zuev.

Ecological Doctrine of the Russian Federation - was developed in the framework of the National Ecological Forum under the leadership of academician RAS Chereshnev and president of RANS Kuznetsov.

The last period of the life of the Academy has been associated with the creation and implementation of a series of innovative high-end technology for the development of key sectors of the Russian economy. Some of them are marked with state awards. I unable to comment on the whole range of technologies. I will point a vivid example in the field of geophysical exploration carried out together with geophysicists from the US state of Texas - is a technology of "direct" the search for oil and gas.

\section{FORUMS AND EVENTS}

It is impossible not to note the following important international forums:

Earth Summit in Johannesburg, Rio +10 , Rio de Janeiro, Geneva, New York (Yakovets, Bolshakov, Geikhman, Kuznetsov, Spitsyn, Shcheulin). 
Youth Earth Summit Tunza 1, Tunza 2 (Dubna) UN Avenue (Doronin, Cheremisina, Molodozhentseva).

National committee "Intellectual resources of Russia". Forums "Intellectual Russia" - Dubna, Moscow, Bryansk, Tambov (Mironov, Kuznetsov, Panov and others).

Global education project "Ecomir" (Ecological Award) (Ivanitskaya, Petrosyan, Kurdyumov).

International Festival of popular films "The World of Knowledge" (St. Petersburg, Lennauchfilm) (Chereshnev, Kapitsa, Kuznetsov).

Astana Economic Forum and energetic-ecological projects of RANS and KazANS (Yakovets, Spitsyn, Abykayev, Bekturganov, Kuznetsov, Shcheulin).

\section{RANS AND SCIENTIFIC DISCOVERIES}

Results of intellectual work of scientists and researchers - scientific discoveries, hypotheses, scientific ideas - are fundamental to the field of knowledge and have a longterm, often a revolutionary impact on the development of world science, but may not always give a quick economic benefit.

In addition to scientific discoveries in the basic sciences for the first time in world practice began to carried out registration of non-traditional intellectual property among social sciences and humanities, as well as scientific ideas and scientific hypotheses. We believe that the registration of the results of intellectual creative work is a powerful incentive for scientists in their work.

There are currently registered 384 scientific discoveries in the field of natural sciences, 41 - in the field of social sciences and humanities, 15 of the scientific ideas and 26 of scientific hypotheses.

I can not mention the problems of perception and discussion in the media of issues related to the recognition of breakthrough technology solutions that often do not fit into traditional notions of classical physics and mathematics.

I recall the statements of one of the brightest mathematicians of the XX century Kurt Godel:

"There will always be true statements, proof of which is not available to us."

"Sophisticated mathematical systems limit themselves in what they can prove."

Two famous Gödel axioms:

Any logically consistent system of equations is incomplete.

Any complete system of equations is logically inconsistent.

Historians of science known well fatal errors ("ban") of outstanding scientists of the world.

So, Stanislaw Lem in his book "Black and White" (AST Publ., Moscow, 2015) in the section "Finger in the sky" gave examples of such predictions.

The great English scientist, President of the Royal Society, William Thomson (Lord Kelvin) stated (1895): the creation of aircraft heavier than air - impossible!

Predicted fast heat death of Planet Earth (excluding domestic energy sources geological processes!).

The famous American physicist Albert Michelson (1903) argued that all important laws of physics are already open!

The largest French scientist Antoine Lavoisier died during the revolution under the guillotine, without accepting biomagnetism and the possibility of falling meteorites.

The list of such allegations of prominent scientists is quite large.

Scientists RANS, including famous Russian physicists Gareyev, Rodionov, Krivitsky put forward someinteresting ideas and hypotheses, which met strong reaction of traditionally thinked of eminent scientists. Without going into a discussion on the so-called pseudo-science, I will give only one example of such pseudoscientific ideas and designs.

I want to draw your attention to the very interesting (recently appeared on the network), an interview with the distinguished professor Malinetskii (Institute of Applied Mathematics Keldysh) "Verified the reactor cold fusion."

It seems that the energy world is on the threshold of new global events. And how many intellectual battles and criticism passed on this subject on the pages of our and foreign editions.

\section{RANS AND EDUCATIONAL FIELD}

The most important activity of the RANS is deeply immersion to the educational process of modern Russia. Most departments of RANS operate within universities. We understand that education - is the most important state-forming activity of scientists (teachers) and the responsibility of the state.

Note that much of the members of the Academy is the leading professors of the best universities, institutes and academies of Russia, USA, Germany, Canada, Kazakhstan, Kyrgyzstan and other countries. Precisely these people bring in the youth audience the fundamental and applied knowledge.

Equally important is the moral foundation of the higher education system. Many of us are worried about the trend "bolognisation" and a sharp increase in the bureaucratization of the educational process. Speaking as a joke, It should not be allowed that "the love of education" would replace the education itself. Entering the classroom, the professor feels the pulse of the audience, sees students eye, who wait from teacher true knowledge and lessons of citizenship.

A separate and very important for Russia today and for international community is the participate of RANS in the creation of the Network Institute of money laundering and terrorist financing. Work is carried out by group of scientists of RANS (Magomedov, Glotov, Ovchinnikov) in close contact with the Federal Service Rosfinmonitoring.

But, of course, the most important product of RANS activity in the field of higher education was the creation in

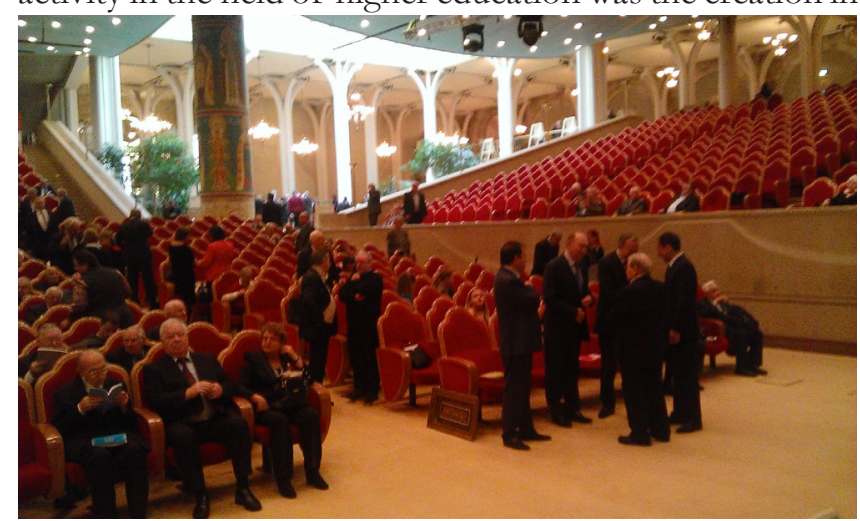


1994 together with the Joint Institute for Nuclear Research (JINR), City Administration Dubna and the Government of Moscow Region of the International University of Nature, Society and Man "Dubna". According to the rector of Lomonosov MSU Academician Sadovnichy and Potanin Foundation experts, university Dubna is one of the best higher educational institutions of Russia.

Especial, intellectual atmosphere of Dubna, with availability of research teams of the highest professional level, as well as versatile areas of research in nuclear physics, nuclear energy, high-tech engineering, served as the basis for the emergence of a fundamentally new for Russia concept university. This concept is an effort to create new generation of specialists with integrative knowledges of nature, society and man, aware of the close relationship of processes and phenomena of the world and with search ways of harmonizing the laws of human nature and society. Today, the university runs a young team led by the rector - doctor of physical and mathematical sciences Fursaev.

\section{PUBLISHING ACTIVITIES RANS}

For 25 years, monographs, collections of papers, encyclopedias in various fields of science, are published directly in the publishing center of RANS, or under the heading of RANS, or with the information about the author of publication - as a member of RANS, consists of thousands of titles.

Already 15 years a large circulation is published public-scientific journal "Bulletin of RANS". Many of the sections and departments of RANS have their own magazines.

In 2009, the RANS established the journal "Radioelectronics. Nanosystems. Information technology" (RENSIT). Rubrics journal show a wide range of studies, which are conducted members of RANS: multidimensional theories of physical fields, dynamic chaos, radiophysics and radiolocation, fractals in physics, physics of condensed matter, nanosystems, information technology, biophysics and medical physics, and others.

An unforgettable event was held in 2000 in Brussels (Russian Embassy in Belgium): Gold Medal Kapitza was awarded to outstanding scientist Ilya Prigogine Nobel laureate. Rewarding medal held RANS President Kuznetsov as well as full members of RANS Basniev and Azizov.

\section{RUSSIAN COSMISTS. VERNADSKY - A SYMBOL OF THE ACADEMY}

RANS and University "Dubna" pay great attention to the history of scientific and philosophical school of Russian cosmism. Anniversaries Lomonosov, Lobachesky, Fedorov, Podolynsky, Tsiolkovsky were noted by conferences, seminars and public lectures.

The symbol of RANS throughout its activities is the Vernadsky. Anniversaries of the great thinker had devoted several conferences "Vernadsky Readings", as well as participate in the unveiling of a monument to Vernadsky in Tambov.

\section{CONCLUSION}

I draw the line under the brief narration of history and formation of the largest public (expert) organization of Russia on a very difficult, dramatic stage in history of country (90 and 00-ies).

Note that the theorems of "existence" and "sustainability" RANS proved. The theorem of "uniqueness" to prove it is not meaningful, since must be many different network structures supporting scientific values and culture of the country.

As an All-Russian scientific organization, RANS plays an important role one of the cells of civil society, around which is consolidating a large domestic intellectual potential of performing a stabilizing role in the country.

The Academy as the organizational structure could not develop without the daily scientific and organizational work and networking. Here the special role belongs to the first Vice-President, Chief Scientific Secretary of the Academy of Ivanitskaya, staff members of the Presidium in Moscow Shumova, Novitskaya, Strelkova, as well as to assistant president of the Academy in Dubna Molodozhentseva.

Dear Colleagues!

Scientists RANS show that the world around us is changing faster and faster, in a growing number of destinations. These changes obeys to the accelerating wave process which accompanied by an increase in free capacity of the system "nature - society - man" and reducing the periods between cycles of evolution of geosphere, biosphere, sociosphere and technosphere. Now is implemented complex path of transition to the noosphere.

For the public consciousness there are new realities, new pictures of the world, a new life-support technologies (including medicine, education, artificial intelligence, robotics, technologies travel in space). Scientists RANS actively participate in the emergence of these new realities.

V.I. Vernadsky wrote: "The energy of the mind is inexhaustible". I think that scientists RANS are able to direct the flow of its energy (free capacities) into the mainstream of the sustainable development of our country and the world around us.

PS. In 1941, the eminent English biologist (zoologist) Richard Dawkins - the author of the sensational monograph "The Selfish Gene" - suggested a new term "MEM" and a new area of knowledge - memetics. In his wording MEM is a unit of transmission of an cultural image of one or the other event or structure.

I believe in what the brand of RANS as a special MEM will continue for decades to come.

\section{Oleg Leonidovich Kuznetsov \\ prof., president of RANS, USSR State Prize winner, Honored Scientist of the RSFSR \\ Russian Academy of Natural Sciences \\ 29/16, Lane Sivtsev Vrazhek, Moscow 119002, Russia info@raen.ru}

